\title{
LOCALIZATION OF EXPANSIN-LIKE PROTEIN IN APOPLAST OF PEA (PISUM SATIVUM L.) ROOT NODULES DURING INTERACTION WITH RHIZOBIUM LEGUMINOSARUM BV. VICIAE 248
}

\author{
MARZENA SUJKOWSKA, WoJCIECH BORUCKI, \\ WŁADYSŁAW GOLINOWSKI \\ Department of Botany, Faculty of Agriculture and Biology \\ Warsaw Agricultural University \\ Nowoursynowska 159, 02-776 Warszawa, Poland \\ e-mail: marzena_sujkowska@sggw.pl
}

(Received: May 5, 2006. Accepted: November 21, 2006)

\begin{abstract}
During nodule development on pea roots, apoplast undergoes changes in activity of plant cell wall proteins such as expansins (EXPs). Because the accumulation of EXP protein has been correlated with the growth of various plant organs, we investigated using Western Blot and immunolocalization studies with antibody against PsEXP1, whether this protein was accumulated in the expanding cells of nodule. Immunoblot results indicated the presence of a 30-kDa band specific for pea root nodules. The EXP proteins content rose during growth of pea root nodules. Expansin(s) protein was localized in nodule apoplast as well as in the infection thread walls. The enhanced amount of expansin-like proteins in meristematic part of nodule, root and shoot was shown. The localization of this protein in the meristematic cell walls can be related to the loosening of plant cell wall before cell enlargement. Both, plant cell enlargement and infection thread growth require activity of expansin(s). Possible involvement of EXPs in the process of pea root nodule development is also discussed.
\end{abstract}

KEY WORDS: expansin, expansive growth, infection threads, nodules, Pisum sativum L., symbiosis.

\section{INTRODUCTION}

Symbiotic interaction between plants and rhizobia is almost completely restricted to leguminous plants and results in the formation of a new organ, the root nodule. Although considerable progress has been made in molecular biology of Rhizobium-Legumes interaction the mechanisms of nodule development is still insufficiently understood. Colonization of plant cells by rhizobium bacteria involves the progressive remodelling of plant-microbial interface. As a result of local modification of the extracellular matrix an endosymbiont such as rhizobium, creates a subcellular point of entry throught the plant cell wall with minimum damage to host cell and with minimum elicitation of defence responses (Parniske 2000). In plant tissues the apoplast is mainly composed of plant cell walls and intercellular spaces. In the root nodule there is an additional apoplast zone, which is represented by infection threads (ITs) present in nodule meristem, infection thread zone, early symbiosis zone and nitrogen fixing zone (Higashi et al. 1986). The synthesis and composition of ITs are thought to be similar to that of the host cell wall, and inside them bacteria become embedded in plant cell wall-like matrix (Newcomb and McIntyre 1981; Rae et al. 1992). The IT arises as a tubular ingrowth of the primary plant cell wall bounded by plant cell wall (Brewin 2004). The IT wall of pea is composed of cellulose, pectins and matrix which contains plant extracellular matrix glycoproteins (Rae et al. 1992). Growth of infection threads involves remodelling of plant cell walls. It is believed that extension growth of the IT probably depends on secretion of matrix glycoproteins into the lumen and on multiplication of rhizobia at the growing tip (Gage 2002).

The growing wall posseses a combination of strength and pliancy, enabling it to withstand the high turgor pressure, while at the same time permitting a controlled polymer 'creep' that distends the wall and enables expansion (Cosgrove 2000b). The walls of expanding vegetative cells exhibit activity of various enzymes that may contribute to a modification of cell wall mechanical properties. Among them expansins are unique in their ability to induce immediate cell wall extension in vitro and in vivo ( $\mathrm{Li}$ et al. 2002). Expansins are a family of small (25-30 kDa) proteins (Cosgrove 1998). They have no known enzymatic activity, but they have the ability to break hydrogen bonds between cellulose microfibrils and matrix polymers when activated by an acidic environment (McQueen-Mason and Cosgrove 1994). EXPs are primarily localized in the 
expansing regions of plants and are belived to be responsible for cell wall loosening that is reqiured for plant cell expansion (Cosgrove 1998).

Expansins are encoded by large gene families whose patterns of transcript accumulation and activity frequently correlate with specific processes of growth, morphogenesis, and differentiation (Cosgrove 2000b). Expansin proteins and their activity have been detected in growing vegetative tissues of several species (Cosgrove and Li 1993; Wu et al. 1996; Chao and Kende 1998). Most of the expansin studies were performed in hypocotyls, stems and leaves of dicotyledonous plants or roots, coleoptiles and internodes of monocots. However, to our knowledge, cytological localization of expansin protein in apoplast of pea root nodules during nodule development has not been analysed so far. Expansins are encoded by large multigene families in all plant species studied so far (Li et al. 2002). Expansin genes have been identified in a range of land plants (http://www. bio.psu.edu/expansins/) bryophytes, ferns (Kim et al. 2000), gymnosperms ( $\mathrm{Li}$ et al. 2002), diverse angiosperms (Cosgrove 2000a), and suspension cultured cells (Link and Cosgrove 1998). So far, only a few expansin genes have been characterized in legume plants (Giordano and Hirsch 2004). Distantly related expansin-like sequences were also identified in the social amoeba, Dictyostelium discoideum, suggesting that these cell wall-localized proteins have a very deep evolutionary origin ( $\mathrm{Li}$ et al. 2002). Expansin-like sequences have been also identified in bacteria, fungi (Cosgrove et al. 2002) and nematodes, where they may aid invasion of plant body (Qin et al. 2004). The action of expansin and expression of expansin genes are commonly associated with fast growing tissues. EXPs play an important role in the expansion and differentiation of plant tissues and organs (Chao and Kende 1998), they are thought to function in cell enlargement, pollen tube invasion of stigma (in grasses) (Cosgrove 2000a), early development of leaf primordia (Fleming et al. 1997), wall disassembly during fruit ripening, abscission, cell separation events (Cosgrove 2000a). Expansins are also a class of cell wall localized proteins upregulated in response to rhizobial inoculation (Giordano and Hirsch 2004). The individual genes can be expressed in different tissues and their expression can be modulated by different stimuli (Lee et al. 2001; Vogler et al. 2003). However, the regulation of expansins by biotic factors has rarely been investigated. The aim of this work was immunolocalization of expansin-like protein in apoplast during pea root nodule development using immunoblotting, immunofluorescence and immunogold experiments.

\section{MATERIALS AND METHODS}

\section{Plant growth}

Surface sterilized pea seeds (Pisum sativum L. cv. Sześciotygodniowy) were germinated at room temperature on Petri dishes. Seedlings with roots ca. $2 \mathrm{~cm}$ long were transferred to pots (four seeds per pot) of 1-liter volume filled with sterile perlite and inoculated with Rhizobium leguminosarum bv. viciae strain 248 (wild type, effective). For five days, both the experimental plants and control plants were watered with distilled water. The experimental plants were watered three times a week with nitrogen-free me- dium according to Fahraeus (1957), while control plants were given the same medium enriched with nitrogen in the form of ammonium nitrate at a concentration of $0.3 \mathrm{~g} / \mathrm{l}$. The plants were cultivated in growth room (400 $\mathrm{\mu m} / \mathrm{m}^{2} / \mathrm{s}$ PAR) under a $16-/ 8$-h photoperiod at the temperature of $20-22^{\circ} \mathrm{C}$ during the day and $14-16^{\circ} \mathrm{C}$ at night.

\section{Protein extraction and immunoblotting}

We determined the localization of a expansin-like protein that cross-reacted with an antibody raised to PsEXP1. The sequence of PsEXP1 (X85187) is $\alpha$-expansin recorded in GenBank. We selected a cDNA fragment corresponding to PsEXP1 (amino acids 232-243 in the sequence). Similarity searches (BLAST software) indicated that the fulllength amino acid sequence of PsEXP1 is highly conserved among $\alpha$-expansins recorded in GenBank. Sequence analysis revealed 87 to $84 \%$ identity and $91,90 \%$ similarity at the amino acid level to the $\alpha$-expansin proteins of Glycine max (GmEXP2), Melilotus alba (MaEXP1), Cucumis sativus (á-EXP6 precursor), Pyrus communis (PcEXP6), Prunus persica (PpEXP3), Rumex palustris (á-EXP11 precursor), Arabidopsis thaliana (AtEXP4). EXP antibody was generated in rabbits by immunizing with the peptide RVTGSDRRTSTS (amino acids 232-243 of the PsEXP1).

The 5, 10, 18 and 27-d-old (days after inoculation) nodules were collected for the investigation. Pea petals and uninfected roots (18-d-old) from control plants were also taken. For isolation of wall-associated proteins, plant material was ground to a powder in liquid nitrogen and homogenized with $50 \mathrm{mM}$ sodium acetate according to McQueen-Mason and Cosgrove (1995). The samples were concentrated on columns (MICROCON YM-10) for $30 \mathrm{~min}$. in $25^{\circ} \mathrm{C}$. Protein concentrations were determined with a protein assay kit (Roche) using bovine serum albumin (BSA) as a standard. Protein extracts $(25 \mu \mathrm{g} / \mathrm{lane})$ were separated by SDS-polyacrylamide gel electrophoresis on a $14 \%$ polyacrylamide gel (Bio-Rad) (Laemmli 1970) and transferred electrophoretically to a nitrocellulose membrane. Membranes where blocked with 3\% BSA in Tris buffered saline (TBS - $10 \mathrm{mM}$ Tris- $\mathrm{HCl}, 150 \mathrm{mM} \mathrm{NaCl}, \mathrm{pH}$ 7.6) for $1 \mathrm{~h}$, washed in three changes of TBS-TWEEN/ TRITON buffer (10 mM Tris- $\mathrm{HCl}, 150 \mathrm{mM} \mathrm{NaCl}, 0.2 \%$ Triton X-100 and $0.05 \%$ Tween 20, pH 7.6) for 30 min and exposed successively to 1:200 diluted rabbit purified anti-PsEXP1 in blocking buffer for $1 \mathrm{~h}$. Rabbit anti-PsExp1 was purified using Protein A Antibody Purification Kit (Sigma). After incubation, membranes were washed as described above. Secondary goat anti-rabbit antibody conjugated with alkaline phosphatase (Sigma) was diluted to 1:20 000 in solution containing $10 \mathrm{mM}$ Tris- $\mathrm{HCl}, 150 \mathrm{mM} \mathrm{NaCl}$, and $5 \%$ skim milk, pH 7.6 for 90 min. After, incubation membranes were washed as described above. Alkaline phosphatase activity was detected using detection buffer $(100 \mathrm{mM} \mathrm{NaCl}, 5$ $\mathrm{mM} \mathrm{MgCl}, 100 \mathrm{mM}$ TRIS-HCl, $\mathrm{pH}$ 9.5) containing BCIP (5-bromo-4-chloro-3-indolyl phosphate) and NBT (nitro blue tetrazolium) prepared according to Sambrook and others (1989).

We determined the localization of a protein cross-reacted with antibody raised to PsEXP1. We performed an immunoblot analysis of proteins from uninfected pea roots and 5 , 10,18 and 27-d-old pea root nodules and as control we isolated proteins from pea petals. 


\section{Immunolocalization}

For immunolocalization experiments the tissue samples where embedded in butyl-methylmethacrylate resin (BMM) (Gubler 1989) for LM; and LR White resin, ultrathin sectioned material (Vandenbosch et al. 1995) for TEM.

Hand sections of nodules and other developing organs of pea (shoot and root apical meristems and young lateral roots) were fixed with $4 \%$ paraformaldehyde MSB buffer for 2 hours at room temperature. Then the material was dehydrated in graded ethanol series and embedded in BMM re$\sin$. The material was sectioned at $2 \mu \mathrm{m}$ on microtome (Jung RMM 2065). After resin removal with acetone, sections were incubated in blocking solution containing $5 \%$ skim milk powder in TBS for $1 \mathrm{~h}$ before application of the primary rabbit antibody. Sections were washed in TBS with $0.05 \%$ Tween 20 and incubated in primary antibody solution (1:20) with $1 \%$ skim milk for $90 \mathrm{~min}$ at room temperature before washing in TBS-Tween and application of secondary $(1: 2000)$ goat anti-rabbit antibody conjugated to Alexa Fluor 488 (Molecular Probes) for $1 \mathrm{~h}$. Control sections were incubated without primary antibody or with preimmune serum (1:20) in incubation medium for $1 \mathrm{~h}$ at room temperature, washed thoroughly as described above, and stained with $0.1 \%$ toluidine blue for $10 \mathrm{~min}$ to minimize tissue autofluorescence. The sections were mounted in immuno-fluore mounting medium (ICN) and examined by fluorescent microscopy (AX Provis, Olympus). Photographs were taken on Kodak Gold 200 negatives, which were eventually scanned using Canoscan 9900F (Canon).

For TEM, nodule sections were fixed as above. Then the material was dehydrated in graded ethanol series and embedded in LR White resin (Vandenbosch et al. 1995). The material was cut with ultramicrotome (Ultracut) at $70 \mathrm{~nm}$ and sections were transferred to 150 -mesh nickel grids. Section were treated with blocking solution $(3 \%$ BSA in TBS) for $1 \mathrm{~h}$ at room temperature, washed in TBS-Tween buffer (TBS with $0.05 \%$ Tween) and incubated in solution containing primary antibody diluted 1:20 for $90 \mathrm{~min}$ at room temperature. Controls were prepared without primary antibody in incubation medium or containing pre-immune serum (1:20). Next, the sections were washed with TBS containing $0.05 \%$ Tween 20 three times for $10 \mathrm{~min}$ each and incubated in goat anti-rabbit antibody (1:50) (Sigma) conjugated with 10-nm colloidal gold particles for $1 \mathrm{~h}$. They were washed as described above and contrasted with $2 \%$ uranyl acetate for $8 \mathrm{~min}$, washed in distilled water and examined under TEM (Morgagni).

\section{RESULTS}

\section{Immunodetection of expansin proteins in nodules}

Immunoblot analysis indicated that the PsEXP1 antibody cross-reacted strongly with approximately $30 \mathrm{kDa}$ peptide in pea nodules, petals and roots (Fig. 1). This protein content in nodules increased up to 18 days past infection. A faint cross-reactive band, at $30 \mathrm{kDa}$, was detected for 27-d-old nodules and uninfected pea roots.

\section{Immunofluorescence and immunogold labelling}

Once we determined that the antibody directed against the pea native expansin cross-reacted with pea root nodule, we have applied the histochemical methods to localize

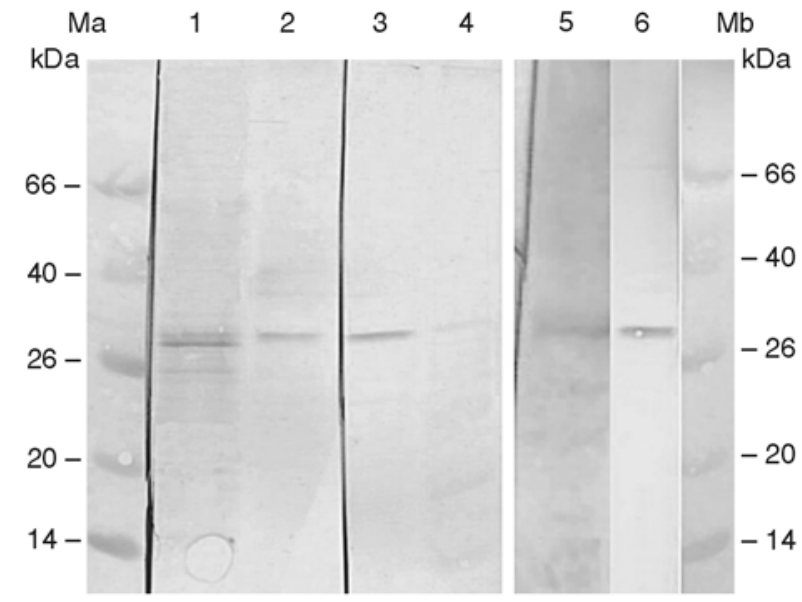

Fig. 1. Detection of expansin in roots, pea petals and nodule tissues. Immunoblot analysis of expansin protein during nodule development in: 5-d-old nodules (1), 10-d-old nodules (2), 18-d-old nodules (3), 27-d-old nodules (4), uninfected pea roots (5), and pea petals (6). Antibody against PsEXP1 cross-reacts strongly with protein from nodule tissue up to 18-day past inoculation and with protein isolated from pea petals at $30 \mathrm{kDa}$. Patchy localization of expansin was observed for 27-d-old nodules and uninfected pea roots. Ma - marker for lanes 1-4; Mb - marker for lanes 5 and 6. Size markers are indicated.

a putative expansin protein during nodules development. Central region of 5-d-old nodules is composed of less vacuolated cells than the other (cortical) region (Fig. 2A). The cortical cells are enlarged and have large central vacuoles. The cells in central part of nodule still divide. Infected cells containing bacteroids are not visible. Infection threads are present in most of these centrally localized cells and in nodule cortical cells. Using immunofluorescence labeling we have localized a protein, which cross-reacts with PsEXP1 antibody. The protein was localized in cell walls and intercellular spaces of dividing cells, the infection threads and in the nodule cortex (Figs 2B and C). Controls without primary antibody (data not shown) and control with pre-immune serum were showing no expansin staining (Fig. 2D). Under electron microscopy level an intense immunogold labelling was visible in the cell walls of young cortex, the meristem and the infection thread walls (Figs. $2 \mathrm{E}$ through $\mathrm{G}$ ), and confirmed fluorescence microscopy observations. Gold granules were observed in the cell walls of nodule cortex cells (Fig. 2E), on walls of infection threads localized in cortex cells (Fig. 2F), in the cell walls of meristematic cells (Fig. 2G). Additionaly Golgi apparatus and Golgi derived vesicles located next to the cell walls also labelled with gold particles (Fig. 2H). The wall of penetrating infection threads showed also gold staining the same as plant cell wall (Fig. 2I). Figure 2J shows no labeling in control with pre-immune-serum in incubation medium. A control without primary antibody in incubation medium (data not shown) revealed no labeling as well.

Comparing with 5-d-old nodules, 10-d-old pea root nodules enlarge in size as a consequence of cells number increase and cells enlargement (Fig. 3A). Nodule meristematic cells differentiate into cortical or bacteroidal tissue cells. The nodule cortical cells are very large especially at the distal region of the nodule near to the meristem. The central region of the nodule is composed of uninfected cells and infected cells releasing rhizobia from the infection threads. Infected cells increase in size and bacteria 

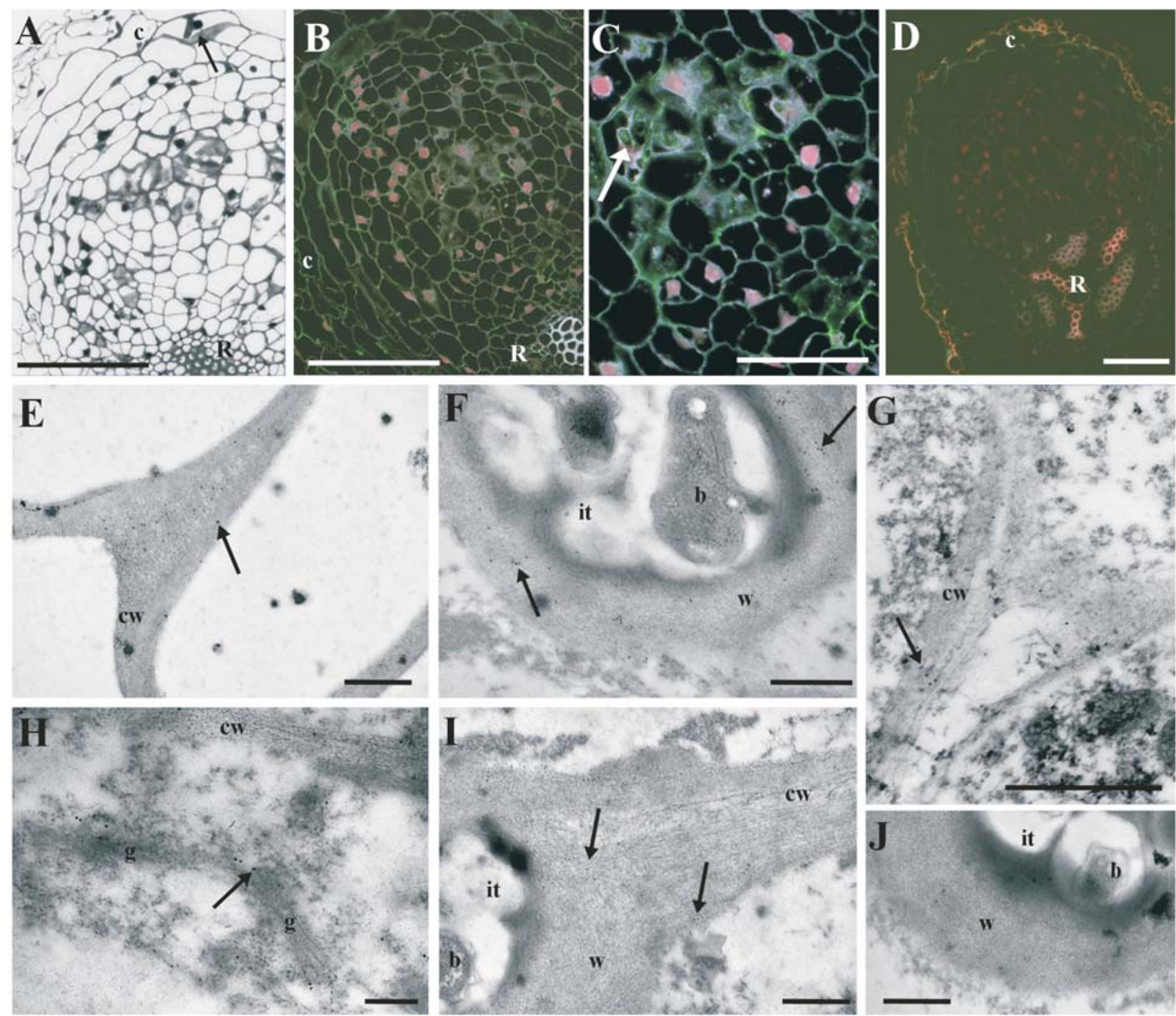

Fig. 2. Detection of expansin in 5-d-old pea root nodule. A - semi-thin section of a 5-d-old pea root nodule. Bright field. Note that centraly located nodule cells have more cytoplasm than cortical cells. In cortex (c) large infection thread is observed (arrow): $\mathrm{c}-$ nodule cortex; $\mathrm{R}-$ root. Bar $=100$ um. B-D - detection of expansin after immunofluorescence labelling. The sections were incubated with antibody raised to PsEXP1. B - section of the nodule. Protein cross-reacting with PsEXP1 is localized in cell walls, intercellular spaces and in nodule cortex (c). Bar = $100 \mu \mathrm{m}$. C - enlarged view of central part of the nodule. Cross-reaction with antibody PsEXP1 is observed in cell walls of dividing cells, intercellular spaces and infection threads (arrow). Bar $=50 \mu \mathrm{m}$. $\mathbf{D}$ - no cross-reacting protein is detected in control with pre-immune-serum. Bar $=100 \mathbf{\mu m}$. E-J - detection of expansin in 5-d-old nodules after immunogold labelling: b - bacteria; cw - cell wall; g - Golgi apparatus; it - infection thread; w - wall of infection thread. E - cortical cell. Gold granules (arrow) are present on the cell wall (cw). F - infection threads (it) with bacteria (b) in cortical cells. After threatment with PsEXP1, an important labelling (arrows) is detectable in infection thread wall $(w)$. Bar $=0.5 \mu \mathrm{m} . \mathbf{G}-$ divinding cells of nodule. Gold granules (arrow) are present on cell walls $(\mathrm{cw})$. Bar $=1 \mu \mathrm{m}$. $\mathbf{H}$ - gold particles are also present near the Golgi apparatus (arrow) and in cell wall (cw). Bar $=0.2 \mu \mathrm{m}$. I - infection thread in divinding cells. Wall of infection thread (w) is labelled by PsEXP1 antibody (arrows) the same as plant cell wall (cw). $\mathbf{J}-$ control with pre-immune-serum. No labelling is visible. Bar $=0.5 \mu \mathrm{m}$.

content (Newcomb 1976). Using immunofluorescence labeling we localized a protein, which cross-reacts with PsEXP1 antibody, which was localized within the cell walls and intercellular spaces of nodule meristem, the nodule cortex, the infection threads as well as in the cell walls of infected and uninfected cells in central region of the nodule (Figs. 3B and C). Controls without primary antibody (data not shown) and control with pre-immune serum showed no staining (Fig. 3D). Immunogold labelling with anti-EXP1 indicated that protein which cross-reacted with antibody was localized in the cell walls of nodule meristem and the walls of infection threads and cell walls of infected cells (Figs 3E through G), and confirm the picture observed by fluorescence microscopy. Gold granules were observed in the cell walls of nodule meristem (Fig. 3E), in walls of infection threads localized near the meristem (Fig. 3F), and in the walls of infection threads as well as in penetrated plant cell walls (Fig. 3G). Coloidal gold labelling was also observed in the infection threads walls during bacteria release (Fig. 3H) and in cell walls of infected cells (Fig. 3I). Figure $3 \mathrm{~J}$ shows no labeling in control with pre-immuneserum in incubation medium. A control without primary antibodies in incubation medium (data not shown) was identical to Figure 3J in terms of showing no staining.

Fully developed (18-d-old) pea root nodules are cylindrical in shape and have an apical, persistent meristem at their distal end (Fig. 4A). Vascular bundles embedded in cortical cells transport assimilates to the nodule and aminoacids from the nodule to the stem. The bacteroidal tissue has its zonation that includes: invasion zone (I) near the meristem which is occcupied by branching infection threads, early symbiosis zone (II) where bacteria are released from the in- 

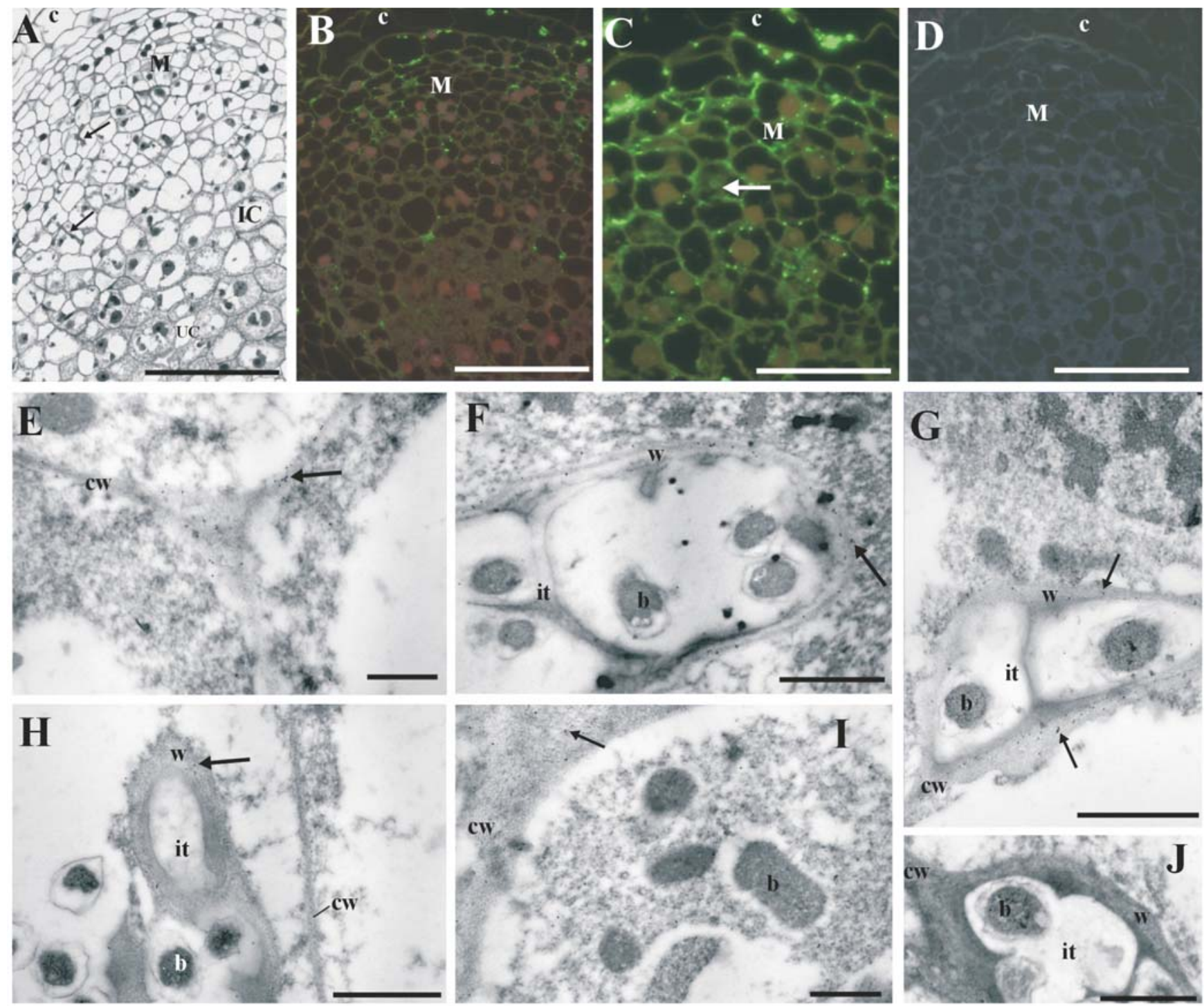

Fig. 3. Detection of expansin in 10-d-old pea root nodule. A - semi-thin section of a 10-d-old pea root nodule. Bright field: c - nodule cortex; IC - infected cell; $\mathrm{M}$ - nodule meristem; $\mathrm{R}$ - root; UC - uninfected cell. A - longitudinal section of a nodule illustrating the large vacuolated cells of the nodule cortex (c), the nodule meristem (M) and central zone of newly infected cells (IC) containing vegetative rhizobia at the periphery of the cytoplasm, infection threads (arrows) and uninfected cells (UC) without bacteria. Bar $=100 \mu \mathrm{m}$. B-D - detection of expansin protein in 10-d-old pea root nodules after immunofluorescence labelling. The sections were incubated with antibody raised to PsEXP1. B - section of the nodule. Protein cross-reacting with PsEXP1 is localized in cell walls of nodule meristem (M), in nodule cortex (c) and in cell walls of cells from central zone. Bar $=100 \mu \mathrm{m}$. $\mathbf{C}-$ enalrgement of cells of apical part of the nodule. Accumulation of a protein cross-reacting to PsEXP1 is localized in cell walls of cortical cells (c), meristem (M), intercellular spaces and infection threads (arrow). Bar $=50 \mu \mathrm{m}$. D - no cross-reacting protein is detected in control with pre-immune-serum. Bar $=100 \mu \mathrm{m}$. E-J - detection of expansin in 10-d-old nodules after immunogold labelling: b - bacteria; cw - cell wall; it - infection thread; w - wall of infection thread. E gold granules (arrow) are present on the cell wall (cw) of nodule meristem. Bar $=0.5 \mu \mathrm{m} . \mathbf{F}$ - infection threads (it) with bacteria (b) near the nodule meristem. After threatment with PsEXP1, an important labelling (arrow) is detectable in infection threads wall (w). G - penetrating infection thread (it) behind the meristem. Gold granules (arrows) are present in cell walls (cw) and wall of infection thread (w). $\mathbf{H}$ - releasing rhizobia (b) from the infection thread (it). Note the presence of label in the wall surrounding infection thread (w). Bar $=1 \mu \mathrm{m}$. I - infected cell with vegetative rhizobia (b). Cell wall (cw) is labelled by PsEXP1 antibody (arrow). Bar $=0.5 \mu \mathrm{m}$. $\mathbf{J}$ - control with pre-immune-serum. Penetrating infection thread (it) behind the meristem. No labelling is visible. $\mathrm{Bar}=1 \mu \mathrm{m}$

fection threads to the plant cells, interzone with large amyloplasts accumulated starch (II/III) and nitrogen fixing zone (III) (Fig. 4A). Immunofluorescence labelling showed similar localization to the 10 -d-old nodules in the cell wall and intercellular spaces of nodule meristem, invasion zone (I) and early symbiosis zone (II) (Figs 4B and C). A higher magnification of the central region of the nodule showed that the cell walls of bacteroids-containning cells containted an expansin protein (Fig. 4C). The signal is not present in uninfected cells. Controls without primary antibody (data not shown) and control with pre-immune serum showed no expansin labelling (Fig. 4D). Immunogold labelling with anti-EXP1 18-d-old nodules indicated that the protein which cross-reacted with antibody was localized in the cell walls of nodule meristem and the walls of infection threads and cell walls of infected cells (Figs. 4E through G), and confirms the fluorescence microscopy observations. Gold granules were observed in the cell wall of nodule meristem (Fig. 4E). Additionaly Golgi apparatus and Golgi derived vesicles located near to the cell walls were also labelled with gold particles (Fig. 4F). The walls of infection threads near the meristem (Fig. 4G) and plant cell wall (Fig. 4H) were also labeled. Very few coloidal gold granules were observed in cell walls of cells from nitrogen fixing zone 

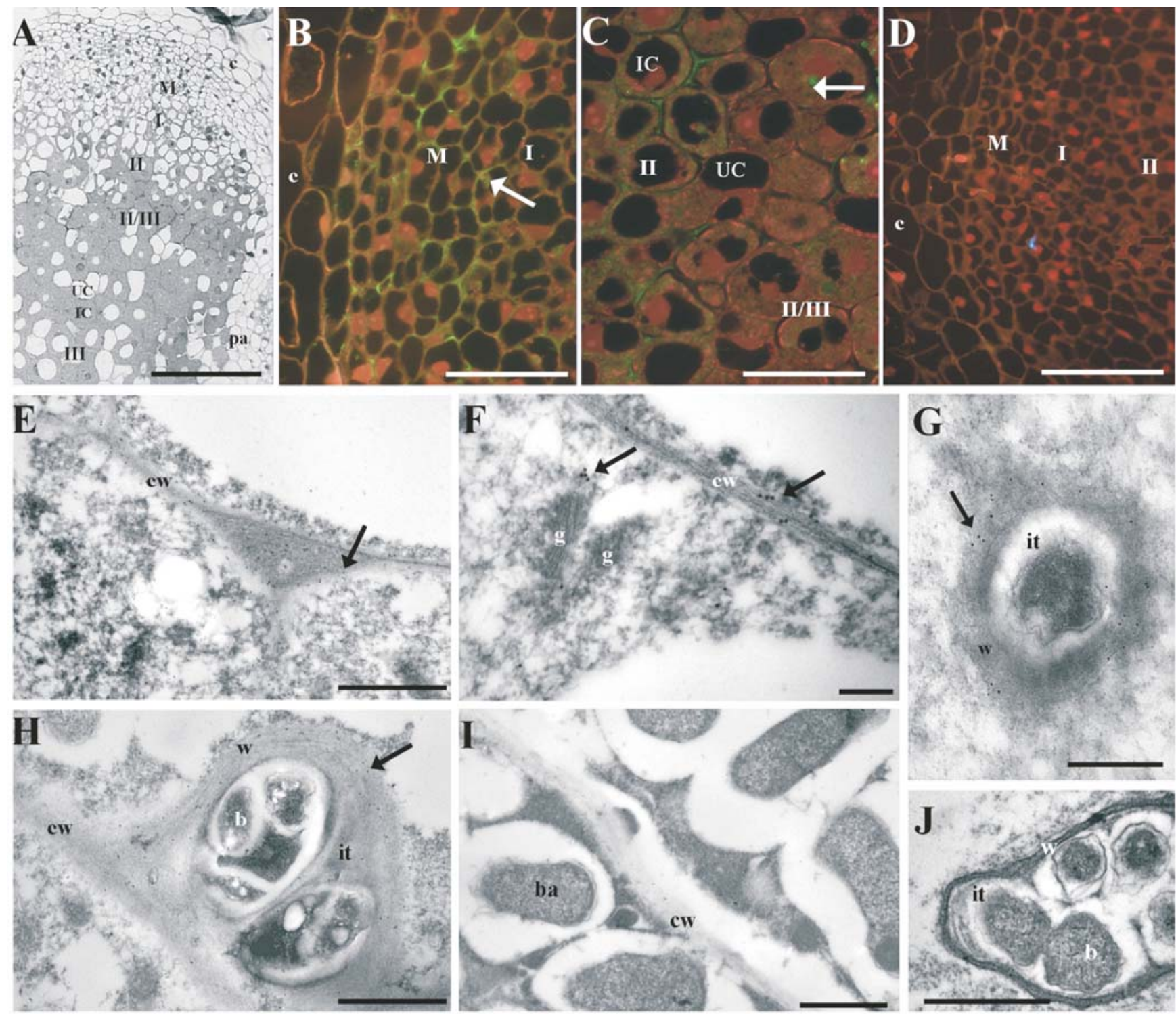

Fig. 4. Detection of expansin in 18-d-old pea root nodules. A - semi-thin sections of a 18-d-old pea root nodule. Bright field: $\mathrm{c}$ - nodule cortex; e - nodule endodermis; IC - infected cell; M - nodule meristem; pa - nodule parenchyma; UC - uninfected cell; I - invasion zone; II - early symbiosis zone; II/III interzone with large amyloplasts; III - nitrogen fixing zone. Bar $=100 \mu \mathrm{m}$. B-D - detection of expansin protein in 18-d-old pea root nodules after immunofluorescence labelling. The sections were incubated with antibody raised to PsEXP1. B - apical part of the nodule. Accumulation of a protein cross-reacting to PsEXP1 is visible in cell walls and intercellular spaces of meristem (M), invasion zone (I) and in infection threads (arrow). C - enlarged view of central part of the nodule. Cross-reaction with antibody PsEXP1 is observed in cell walls and intercellular spaces of cells from early symbiosis zone (II) and also in infection threads (arrow). Bar $=50 \mu \mathrm{m}$. D - no cross-reacting protein is detected in control with pre-immune-serum. Bar $=100 \mu \mathrm{m}$. E-J - detection of expansin in 18-d-old nodules after immunogold labelling: b - bacteria; ba - bacteroid; cw - cell wall; g - Golgi apparatus; it - infection thread; $\mathrm{w}$ - wall of infection thread. $\mathbf{E}$ - gold granules (arrow) are present in the cell wall (cw) of nodule meristem. Bar $=1 \mu \mathrm{m}$. $\mathbf{F}$ - accumulation of labelled material (arrows) are also present near the Golgi apparatus (g) and in cell wall (cw). Bar $=0.2 \mu \mathrm{m}$. G - infection threads (it) near the meristem of nodule. Gold granules (arrow) are present in the infection thread wall (w). $\mathbf{H}-$ an infection thread (it) behind the meristem. Gold granules (arrow) are present in cell walls (cw) and wall of infection thread (w). I - nitrogen fixing zone. Very few gold granules are evident in cell wall (cw) after treatment with antibody PsEXP1. J - no cross-reacting protein is detected in control with pre-immune-serum. Bar $=1 \mu \mathrm{m}$.

(Fig. 4I). Figure 4J shows no labeling in control with preimmune-serum in incubation medium. A control without primary antibody in incubation medium (data not shown) revealed no labeling.

The senescent zone (IV) appears in 27-day-old nodules, where bacteroids and plant cells undergo degeneration at the end point of the symbiotic interaction (Fig. 5A). There was no labelling at this stage of nodule development (Figs $5 \mathrm{~B}$ and $\mathrm{C}$ ). A higher magnification of the nodule apical region showed no staining in the cell walls of meristem (Fig. 5C). Control without primary antibody (data not shown) and control with pre-immune serum showed no expansin staining (Fig. 5D). A very few gold particles labelled meri- stematic cell walls (Fig. 5E), and the walls of infection threads (Figs $5 \mathrm{~F}$ through $\mathrm{H}$ ) of 27 -d-old nodules. The cell walls of nitrogen fixing zone did not reveal the presence of coloidal gold labelling (Fig. 5I). Figure 5J shows no labeling in control with pre-immune-serum in incubation medium. A control without primary antibody in incubation medium (data not shown) revealed no labeling as well.

\section{Immunodetection of expansin proteins in meristems of pea seedlings}

We have investigated immunofluorescence localization of expansin proteins which cross-reacted with PsEXP1 antibody in other meristems of pea plants e.g. shoot apical 

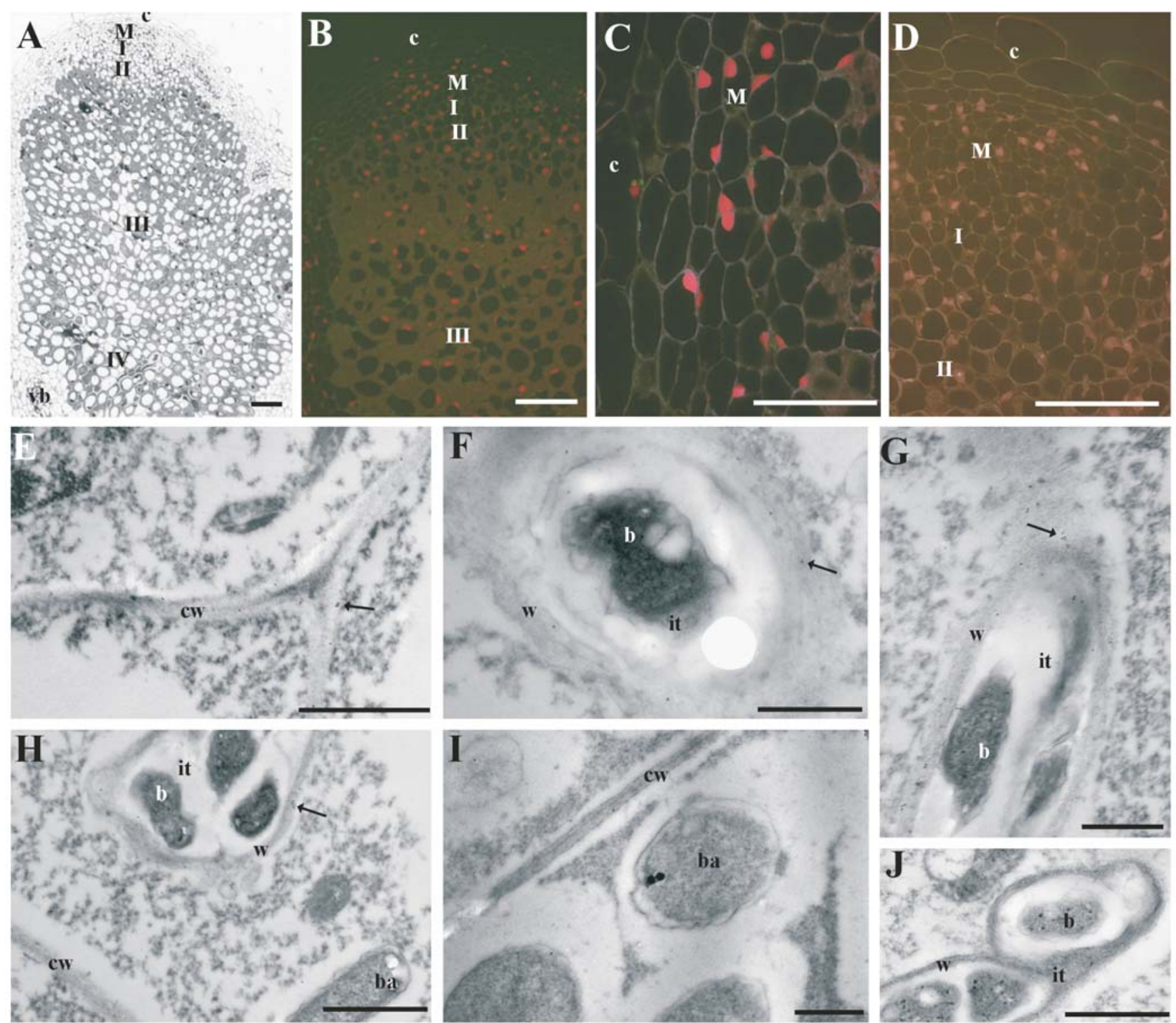

Fig. 5. Detection of expansin in 27-d-old pea root nodules. A - semi-thin sections of a 27-d-old pea root nodule. Bright field: $\mathrm{c}$ - nodule cortex; M - nodule meristem; vb - vascular bundle; I - invasion zone; II - early symbiosis zone; III - nitrogen fixing zone; IV - senescent zone. Bar = 100 $\mu$ m. B-D - detection of expansin protein in 27-d-old pea root nodules after immunofluorescence labelling. The sections were incubated with antibody raised to PsEXP1. $\mathbf{B}$ - no accumulation of a protein cross-reacting to PsEXP1 is observed. Bar $=100 \mu \mathrm{m}$. $\mathbf{C}-$ magnification of nodule mersiem (M). No signal is found in this region. Bar $=50 \mu \mathrm{m}$. $\mathbf{D}$ - no signal is found in control section with pre-immune-serum. Bar $=100 \mu \mathrm{m}$. E-J - detection of expansin in $27-\mathrm{d}-\mathrm{old}$ nodules after immunogold labelling: b - bacteria; ba - bacteroid; cw - cell wall; it - infection thread; w - wall of infection thread. E - some gold granules (arrow) are present in the cell wall (cw) of meristem. Bar $=1 \mu \mathrm{m} . \mathbf{F}$ - very few gold granules (arrow) are present in wall of infection threads (it) near the nodule meristem. $\mathbf{G}$ - penetrating infection thread (it) behind the meristem. Gold granules (arrow) are present in wall of infection thread (w). Bar $=0.5 \mu \mathrm{m}$. $\mathbf{H}-$ early symbiosis zone. Very few gold granules (arrow) are present in wall of infection thread (w) but not in the plant cell wall (cw). Bar $=1 \mu \mathrm{m}$. I - nitrogen fixing zone. No labelling is present in cell wall $(\mathrm{cw})$ after treatment with antibody PsEXP1. Bar $=0.5 \mu \mathrm{m}$. $\mathbf{J}-$ no cross-reacting protein is detected in control with pre-immune-serum. Bar $=1 \mu \mathrm{m}$.

meristem (Figs 6A through D), young lateral root meristem (Figs 6E through $\mathrm{G}$ ), and the main root apical meristem (Figs $6 \mathrm{H}$ through $\mathrm{K}$ ). As shown in Figures $6 \mathrm{~B}$ and $\mathrm{C}$, the expansin proteins were detected in the cell walls of apical shoot meristem and leaf primodium, which mostly comprises the region of cell division and elongation. No cross-reacting protein was detected in control with pre-immune-serum (Fig. 6D). Immunofluorescence labelling of young lateral roots indicated the presence of signal in cell walls of root cap, epidermal cells and developing vascular cylinder (Fig. 6F). No cross-reacting protein was detected in control with pre-immune-serum (Fig. 6G). Figure 6 (I and J) shows immunolocalization of expansin protein in the root apical meristem. The expansin proteins were detected in the cell walls of apical root meristem and root cap (Fig. 6I). A higher magnification of developing vascular cylinder showed intense labelling on walls of procambial cells (Fig. 6J). No cross-reacting protein was detected in control with pre-immune-serum (Fig. 6K).

\section{DISCUSSION}

It has been proposed that modulation of cell wall extensibility could play a key role in plant morphogenesis (Green 1997). Expansins functions in vivo is to modulate cell wall extensibility and therebly regulate organ growth and morphogenesis (Fleming et al. 1997; Link and Cosgrove 1998; 

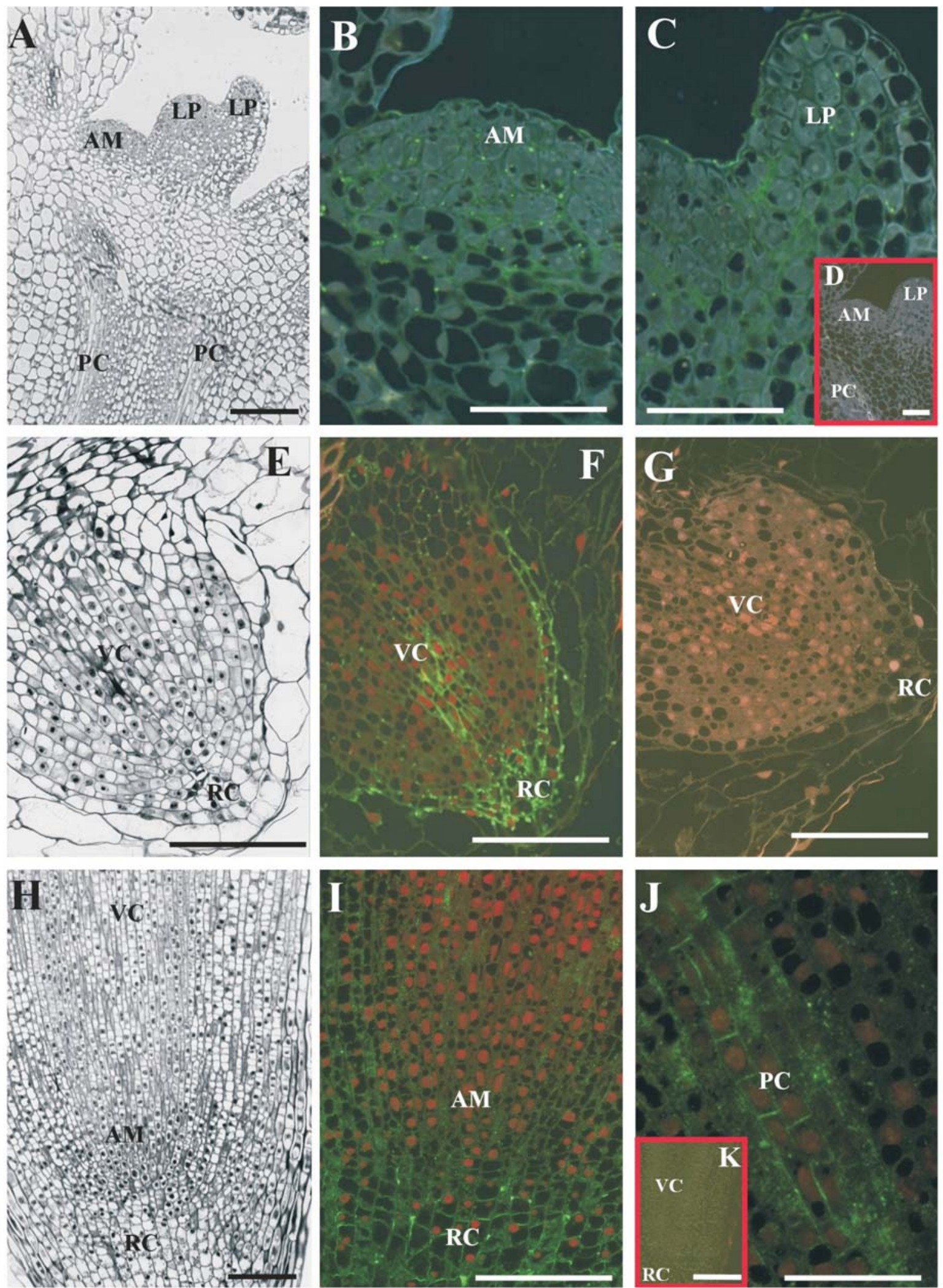

Fig. 6. Detection of expansin in meristems of pea seedlings after immunofluorescence labelling. A - longitudinal sections of a shoot apex harvested from 5-d-old pea seedlings: AM - apical meristem; LP - leaf promodium; PC - procambium. Bar $=100 \mu \mathrm{m}$. B-D - detection of expansin protein. $\mathbf{B}-$ protein cross-reacting to PsEXP1 is detected in the cell walls of the apical meristem (AM). C - protein cross-reacting to PsEXP1 is detected in the cell walls of leaf primordium (LP). $\mathbf{D}$ - no cross-reacting protein is detected in control with pre-immune-serum. Bar $=50 \mu \mathrm{m}$. $\mathbf{E}-$ longitudinal sections of young lateral root: RC - root cap; VC - vascular cylinder. F and $\mathbf{G}$ - detection of protein cross-reacting with PsEXP1. F - strong localization is observed in the cell walls of root cap (RC), epidermal cells and vascular cylinder (VC). G - no staining is detected in control with pre-immune-serum. Bar $=100 \mu \mathrm{m}$. $\mathbf{H}-$ longitudinal sections of root apex of 5-d-old pea seedlings: AM - apical meristem; RC - root cap; VC - vascular cylinder. I-K - detection of expansin proteins. I - cross-reaction with antibody PsEXP1 is observed in cell walls of root cap (RC) and in meristem (AM). Bar $=100 \mu \mathrm{m}$. $\mathbf{J}-$ enlarged view of procambial cells (PC) showing localization of a protein cross-reacting with PsEXP1 in cell walls. Patchy localization of PsEXP1 is observed in cytoplasm of this cells. Bar $=50 \mu \mathrm{m}$. $\mathbf{K}-$ no cross-reacting protein is detected in control with pre-immune-serum. $\mathrm{Bar}=150 \mu \mathrm{m}$. 
Cho and Cosgrove 2000). In legumes, however, it is unclear how many members of expansin genes family exist. In pea only one expansin gene (PsEXP1) has been identified (Michael 1996) so far.

The immunoblot experiment with antibody raised against PsEXP1 identified one band corresponding to $30 \mathrm{kDa}$ in cell walls of developing pea root nodules. The moleclar weigh of this protein is very similar to other $\alpha$-expansins which are small (25-30 kDa) proteins (Cosgrove 1998). There is little information about expansin role in symbiotical interactions (Balestrini et al. 2005). Giordano and Hirsch (2004) showed that an MaEXP1 mRNA was present in root and 20-d-old nodule meristem of Melilotus alba. However, in their studies immunolocalization showed weak staining in the nodule meristem. They sugested that this may reflect the low level of transcript accumulation or this may result from the the fact that cells of this region are tightly packed. The same results were obtained by Zhang and Hansenstein (2000) with maize root meristem. Our immunolabelling experiments demonstrate the presence of abudant epitopes recognized by anti-EXP1 in the walls of dividing and growing cells and infection threads in 5 and 10 old nodules. In 18 day-old nodules expansin protein was detected in walls of growing cells: this included meristem, the invasion zone, early symbiosis zone and interzone II/III but expansin staining gradually ceased with greater distance from the meristem. Weak staining of nodule cortex was also detected. Additionaly Golgi apparatus and Golgi derived vesicles located near to the cell walls also labelled with gold particles, indicated that expansin protein is delivered to the cell walls via common secretory pathway. In mature nodules (27-d-old) we observed the lack of expansin staining in meristem and other parts of pea root nodules. This may correlate with inhibition of meristem activity in this stage of nodule development. Immunogold experiments demonstrate the abundance of epitopes recognized by antiPsEXP1 on cell walls of nodule meristem, growing nodule cells and walls of infection threads in 5, 10 and 18-d-old nodules. These results are confirmed by immunofluorescent studies. Differentiation of meristematic cells involves their enlargement, which must be co-ordinated with the cell wall growth. The nodule meristem gives a rise to cells that differentiate into bacteroidal tissue and peripheral cells. As shown for other plant tissues, accumulation of expansin-like proteins in nodule tissues correlates with expansion activities of their cells. Immunogold experiments indicate that the expansin proteins may also be necessary for IT growth. IT being developed from radicular root hairs are subapically growing structures and must grow and extend with the same mechanisms which made possible the growth of root hairs before the infection (Gage 2004). Our results demonstrate, for the first time, that expansin-like proteins, recognized by anti-PsEXP1, are required for nodule cells and infection threads growth.

Several lines of evidence suggest that local growth processes in plants can be initiated by cell expansion, with cell division being a secondary event (see review Jacobs 1997). Formation of organ initial involves oriented cell expansion and cell wall modification coupled with controlled cell division (Fleming et al. 1997; Jacobs 1997). Legume nodules differ from lateral roots in their developmental origin, type of meristem, vasculature, hormone levels, and other features (Hirsch and LaRue 1997). However, in our study both nodules and emerging lateral roots express expansin proteins in regions where cell elongation or expansion takes place. We also observed labelling of the cell walls of vascular tissue, consistent with the results obtained by Balestrini et al. (2005) in roots during colonization by arbuscular mycorrhizal fungus, and by Chao and Kende (1998) in deepwater rice internodes. Our experiments reveal that expansin-like proteins are abundant in emerging leaf primodium, in root apical meristem and in root cap and vascular tissue as well as in nodule meristem. These results corroborate the earlier data. EXPs were localized in shoot apical meristems (Reinhardt et al. 1998, 2000; Pien and others 2001; Vogler et al. 2003), root tips of primary and secondary roots (Cho and Kende 1998; Zhang and Hasenstein 2000; $\mathrm{Wu}$ et al. 2001). The highest levels of EXP mRNA were found in tomato shoot meristem (Reinhardt et al. 1998). Pien et al. (2001) have demonstrated that a localized induction of the wall-loosening expansins in the shoot apical meristem is sufficient to induce a leaf primordium and set into motion all of the events needed to produce a mature leaf. Reinhardt et al. (2000) obtained similar results by a localized application of auxin. Zhang and Hasenstein (2000) reported the presence of $\alpha$-expansins on the root cap cell wall, suggesting a role in the cell separation process during the sloughing of root cap cells.

\section{CONCLUSIONS}

Our results indicate that: (A) an enhanced amount of expansin-like proteins is present in meristematic parts of nodule, roots and shoot, (B) expansin(s) protein is localized in nodule apoplast including infection thread walls, (C) the localization of EXP protein in the meristematic cell walls can be related to the loosening of plant cell walls during cell enlargement, (D) both, the plant cell enlargement and infection thread growth require activity of expansin(s). Our results suggest that cell-wall-loosening agents like $\alpha$ expansins are important in infection threads growth and their penetration through the plant apoplast.

\section{ACKNOWLEDGEMENTS}

We thank Ewa Znojek for her expert technical assistance. This work was partially supported by the KBN (grant no. 2PO6A00628).

\section{LITERATURE CITED}

BALESTRINI R., COSGROVE D.J., BONFANTE P. 2005. Differential localization of $\alpha$-expansin proteins during the accomodation of root cells to an arbuscular mycorrhizal fungus. Planta. 220: 889-899.

BREWIN N.J. 2004. Plant cell wall remodelling in the Rhizobium-legume symbiosis. Critic. Rev. Plant Sci. 23: 293-316.

CHAO, H.T., KENDE H. 1998. Tissue localization of expansins in deepwater rice. Plant J. 15: 805-812.

CHO H.-T., COSGROVE D.J. 2000. Altered expression of expansin modulates leaf growth and pedicel abscission in Arabidopsis thaliana. Proc. Natl. Acad. Sci. USA 97: 9783-9788.

COSGROVE D.J. 1998. Cell wall loosening by expansins. Plant Physiol. 118: 333-339. 
Cosgrove D.J. 2000a. New genes and new biological roles for expansins. Curr. Opin. Plant Biol. 3: 73-78.

COSGROVE D.J. 2000b. Loosening of plant cell walls by expansins. Nature (London). 407: 321-326.

COSGROVE D.J., LI Z.-C. 1993. Role of expansin in development and light control of growth and wall extension in oat coleoptiles. Plant Physiol. 103: 1321-1328.

COSGROVE D.J., LI L.C., CHO H.T., HOFFMAN-BENNING S., MOORE R., BLECKER D. 2002. The growing world of expansins. Plant Cell Physiol. 43: 1436-1444.

FAHRAEUS G. 1957. The infection of clover root hairs by nodule bacteria studied by single glass slide technique. J. Gen. Microbiol. 16: 374-381.

FLEMING A.J., MCQUEEN-MASON S.J., MANDEL T., KUHLEMEIER C. 1997. Induction of leaf primordia by the cell wall protein expansion. Science 276: 1415-1418.

GAGE D.J. 2002. Analysis of infection thread development using Gfp- and DsRed-expressing Sinorhizobium meliloti. J. Bacteriol. 184: 7042-7046.

GAGE D.J. 2004. Infection and invasion of roots by symbiotic, nitrogen-fixing Rhizobia during nodulation of temperate legumes. Micro. Mol. Biol. Rev. 68: 280-300.

GIORDANO W., HIRSCH A.H. 2004. The expression of MaE$\mathrm{XP1}$, a Melilotus alba expansin gen, is upregulated during the sweetclover-Sinorhizobium meliloti interaction. Mol. PlantMicrobe Interact. 17: 613-622.

GREEN P.B. 1997. Expansin and morphology: a role for biophysics. Trends Plant Sci. 2: 365-366.

GUBLER F. 1989. Immunofluorescence localisation of microtubules in plant root tips embedded in butyl-methyl methacrylate. Cell Biol. Int. Rep. 13: 137-145.

HIRSCH A.M., LARUE T.A., 1997. Is legume nodule a modified root or system or an organ sui generis? Crit. Rev. Plant Sci. 16: 361-392

HIGASHI S., KUSHIYAMA K., ABE M. 1986. Electron microscopic observations of infection threads in driselase treated nodules of Astragalus sinicus. Can. J. Microbiol. 32: 947-952.

JACOBS T. 1997. Why plant cell divide? Plant Cell. 9: 1021-1029.

KIM J.J., CHO H.T., KENDE H. 2000. $\alpha$-expansins in the semiaquatic ferns Marsilea quadrifolia and Regnellidium diphyllum: Evolutionary aspects and physiological role in rachis elongation. Planta. 212: 85-92.

LAEMMLI U.K. 1970. Cleavage of structural proteins during the assembly of the head of bacteriophage T4. Nature. 277: 680-685.

LEE Y., CHOI D., KENDE H. 2001. Expansins: ever-expanding numbers and functions. Curr. Opin. Plant Biol. 4: 527-532.

LI Y., DARLEY C.P., ONGARO V., FLEMING A., SCHIPPER O., BALDAUF S., MCQUEEN-MASON S.J. 2002. Plant expansins are a coplex multigene family with an ancient evolutionary origin. Plant Physiol. 128: 854-864.

LINK B.M., COSGROVE D.J. 1998. Acid-growth response and $\alpha$-expansins in suspension cultures of bright yellow 2 tobacco. Plant Physiol. 118: 907-916.

MCQUEEN-MASON S.J., COSGROVE D.J. 1994. Distribution of hydrogen bonding between plant cell wall polymers by proteins that induce wall extension. Proc. Natl. Acad. Sci. USA 91: 6574-6598.

MCQUEEN-MASON S.J., COSGROVE D.J. 1995. Expansin model of action on cell walls. Analysis of wall hydrolysis, stress relaxation, and binding. Plant Physiol. 107: 87-100.
MICHAEL A.J. 1996. A cDNA from pea petals with sequence similary to pollen allergen, cytokinin-induced and genetic tumour-specific genes: Identification of a new family of related sequences. Plant Mol. Biol. 30: 219-224.

NEWCOMB W. 1976. A correlated light and electron microscopic study of symbiotic growth and differentiation in Pisum sativum root nodules. Can. J. Bot. 54: 2163-2186.

NEWCOMB W., MCINTYRE L. 1981. Development of root nodules of mung bean (Vigna radiata): a reinvestigation of endocytosis. Can. J. Bot. 59: 2478-2499.

QIN L., KUDLA U., ROZE E.H.A., GOVERSE A., POPEIJUS H., NIEUWLAND J., OVERMARS H., JONES J.T., SCHOTS A., SMANT G., BAKKER J., HELDER J. 2004. Plant degradation. A nematode expansin acting on plants. Nature. 427: 30.

PARNISKE M. 2000. Intracellular accomodation of microbes by plants: a common developmental program for symbiosis and disease? Curr. Opin. Plant Biol. 3: 320-328.

PIEN S., WYRZYKOWSKA J., MCQUEEN-MASON S.J., SMART C., FLEMING A., 2001. Local expression of expansin induces the entire process of leaf development and modifies leaf shape. Proct. Natl. Acad. Sci. USA 98: 11812-11817.

RAE A.L., BONFANTE-FASOLO P., BREWIN N.J. 1992. Structure and growth of infection threads in the legume symbiosis with Rhizobium-leguminosarum. Plant J. 2: 385-395.

REINHARDT D., WITTWER F., MANDEL T., KUHLEMEIER C., 1998. Localized upregulation of a new expansin gene predicts the site of leaf formation in the tomato meristem. Plant Cell. 10: 1427-1437.

REINHARDT D., MANDEL T., KUHLEMEIER C. 2000. Auxin regulates the initiation and radial position of plant lateral organs. Plant Cell. 12: 507-518.

SAMBROOK J., FRITSCH E.F., MANIATIS T. 1989. Molecular cloning: A Labolatory Manual, 2nd ed. Cold Spring Harbor Labolatory Press, New York: Cold Spring Harbor Labolator. p. 18.74 .

VANDENBOSCH K., SHERRIER D.J., DREYER D. 1995. Light microscopic applications in immunocytochemistry. Plant Mol. Biol. Manual G3. p. 1-18.

VAN DE WIEL C., SCHERES B., FRANSSEN H., VAN LIEROP M.J., VAN LAMMEREN A., VAN KAMMEN A., BISSELING T. 1990. The early nodulin transcript ENOD2 is located in the nodule parenchyma (inner cortex) of pea and soybean root nodules. EMBO J. 9: 1-7.

VOGLER H., CADERAS D., MANDEL T., KUHLEMEIER C. 2003. Domains of expansin gene expression define growth region in the shoot apex of tomato. Plant. Mol. Biol. 53: 267-272.

WU Y.W., THORNE E.T., SHARP R.E., COSGROVE D.J. 2001. Modification of expansin transcript levels in the maize primary root at low water potential. Plant Physiol. 126: 1471-1479.

WU Y., SHARP R.E., DURACHKO D.M., COSGROVE D.J. 1996. Growth maintenance of the maize primary root at low water potentials involves increases in cell wall extensibility, expansin activity and wall susceptibility to expansins. Plant Physiol. 111: 765-772.

ZHANG N., HASENSTEIN K.H. 2000. Distribution of expansins in gravi-responding maize roots. Plant Cell Physiol. 41: 1305-1312 . 